Оригинални научни рад

УДК 13-821.163.42.09 Гундулић И.

Примљен: 11. јануара 2021.

Прихваћен: 22. јануара 2021.

Мирјана П. Кртолица ${ }^{1}$

https://doi.org/10.46630/phm.13.2021.08

Универзитет у Нишу

Филозофски факултет ${ }^{2 * *}$

Департман за српску и компаративну књижевност

\title{
ГУНДУЛИЋЕВ ОСМАН ИЗМЕЪУ ХАМАРТИЈЕ И ХИБРИСА: ЖРТВА МЛАДОСТИ ИЛИ СВОЈЕ ОХОЛОСТИ?
}

\begin{abstract}
Предмет овог рада је анализа лика султана Османа II представљеног у Гундулићевом епу Осман. Приликом анализе овог епа теоретичари су углавном указивали на његов однос према историји, начину на који је уклопио конвенције барокне поетике у овај еп, а када су анализирали Османов лик, нарочито су истицали амбивалентни однос који је Гундулић имао према турском султану - охолом, а неискусном. У литератури је истицано да Гундулић има разумевања према Осману и његовим поступцима, јер је султан у тренуцима доношења одлука био млад. Такав приступ главном јунаку, доводи нас у дилему и наводи нас да се запитамо да ли је Осман само жртва своје младости или је његов трагични крај последица охолости као једног од седам смртних грехова у хришћанској теологији. Анализа Османовог лика помогла нам је да утврдимо да ли Османа можемо тумачити као трагичног јунака и оправдати његове поступке младошћу, грешкама учињених из незнања - хамартијом или је његов трагични крај последица охолости, дрскости и претеране самоуверености - хибриса. Тема рада биће Османов пад, условљен његовим неискуством и непознавањем ствари или претераном гордошћу и надменошћу. Циљ овог рада је да изложимо чињенице које говоре у корист тврдњи да је Осман пример особе коју борба за моћ може да заслепи и да су његове грешке, иако је Гундулић, како тврде неки теоретичари, покушао да нађе оправдања за делање „охолог дијетета“, настале јер је мислио да може да учини оно чему није дорастао и тако се оглушио о божје законе, које је проповедала католичка црква.
\end{abstract}

Кључне речи: Џиво Гундулић, барокни еп, еп Осман, лик Осман II, хамартија, хибрис, трагични јунак, охолост

1 mirjanakrtolica93@gmail.com

2 Пројекат „Истраживање књижевне прошлости и садашњости на простору југоисточне Србије“, број 01-11-16-1/360 


\section{1. СТВАРАЛАШТВО ЏИВА ГУНДУЛИЋА У КОНТЕКСТУ БАРОКНОГ ЕПА}

Еп је у бароку био омиљена и доминантна књижевна врста. Разлог томе свакако јесте орјентисање барока ка античким узорима. Угледањем на строге нормативне поетике античких стваралаца и теоретичара, барокним писцима су била добро позната правила за састављање епа, које су они у формалном слислу, готово доследно, следили. Међутим, еп у бароку се тематски морао усмерити ка савременим темама, које је прокламовала епоха. За разлику од разуздане ренесансе и жеље да се сваки дан искористи и живи као да је последњи, барок човека подсећа да је све у животу пролазно и да је извесна само смрт. Тако је ова епоха дала „смрти најзначајније и неумитније место у људском животу.“ (TODOROVIĆ 2012: 35) Црква је имала одлучну намеру да сваки вид раскалашности укроти, перманентим подсећањем на смрт и на награду која долази после ње, уколико човек живи у складу са Богом и његовим законима.

Џиво Гундулић је најзначајнији писац барокног епа и уједно најупечатљивији писац барока старог Дубровника. „У дубровачком барокном епском песништву, ни међу спевовима ни међу еповима, ниједно од многобројних дела ове врсте, ствараних до првих деценија XVIII века, није достигло уметнички ниво Гундулићевих.“ (BOJOVIĆ 2014: 10) Гундулић је имао срећу да су његови савременици препознали какав таленат поседује за писање и колико су естетски вредна његова дела, тако да је као велики писац за живота добио признање „краља илирске поезије“. Аутор је драма које су Дубровчани радо волели да гледају (Галатеа, Дијана, Армида, Посветилиште тьвеног, Прозерпина уграблена, Черера, Клеопатра, Аријадна, Коралька од Шира), препева седам библијских покајничких псалама краља Давида, рефлексивно-религиозног спева Сузе сина разметнога, пасторалне драме Дубравка и историјско-романтичног епа Осман.

Иако је незахвално поредити значај и уметничку вредност Гундулићевих књижевних производа, можда највећи допринос дубровачкој књижевности дао је својим епом Осман. Разлог томе јесте чињеница да је Осман био „први дубровачки велики еп на народном језику, састављен према законима нове поетике." (BOJOVIĆ 1995: 10) Не можемо са сигурношћу да тврдимо да ли је Гундулићев у односу на епове других писаца био изузетан, због његовог уметничког израза, језика и стила или због тога што је Гундулић приликом састављања Османа одступио од појединих ставова нормативне поетике и тако успео да постане оригинални састављач епа. 


\section{1. ЏИВО ГУНДУЛИЋ И НОРМАТИВНА ПОЕТИКА. ОСМАН КАО ОДСТУПАЮЕ ОД ПРАВИЛА И СТВАРАЮЕ НОВЕ ПОЕТИКЕ}

Окретајући се античким узорима, барокним писцима су биле на располагању такозване „узорне поетике“: Поетика Торквата Таса је била један од поетика, коју су састављачи епова могли следити. Стварајући своје капитално дело и Гундулић је могао беспоговорно пратити захтеве нормативне поетике, које је барок са одушевљењем прихватио. Међутим, чинећи свесна одступања успео је да створи сопствену поетику, никада не заборављајући да нагласи оно што је епоха прокламовала, а шта је уједно било и део његовог личног убеђења. До састављања сопствене поетике и погледа на књижевност али и живот Гундулић је „долазио на два начина: изучавајући поетике и читајући велика епска дела прошлог и његовог времена." (PANTIĆ 1967: 18) Он је добро познавао античку поетику и узоре које је требало следити приликом писања епа. У његовој свести били су песници Хомер и Вергилије, Аристотелова Ars poetica, a добро је разумео и савремену поетику Торквата Таса.

Гундулић није био одметник од своје епохе, јер је делио њена схватања и заступао њене тежње, али приликом састављања епа Осман није прихватио сва правила a priori већ је себи дао за право да од њих у извесној мери одступи. Одударања од Тасове поетике најпре су се тицала избора материје за ово дело. Тасо је у свом тексту „Говори о песничкој вештини“ јасно објаснио правила која би требало поштовати приликом формирања епа. Поред дидактиче и забавне функције епа, морао је имати прикладну епску форму од чега Гундулић није одступио. Материју за писање епа, песници не треба да измишљају, већ је морају потражити у историји и то хришћанској, никако паганској, тако да она није ни сувише блиска ни сувише далека садашњости. Гундулић је за предмет обраде узео догађај из хришћанске историје, међутим тај догађај је припадао блиској прошлости. Гундулић је имао ваљане разлоге због којих се оглушио о ово Тасово стриктно правило. Битка код Хоћина као материја за сатављање епа била је погодна за спајање две визије - хришћанске и словенске. Неоспорна је чињеница да је Гундулић био велики патриота и дубоко осећао бол и патње кроз које су пролазила његова словенска браћа. Он није био једини дубровачки песник патриотски орјентисан јер у „дубровачкој књижевности 17. века испољено је наглашено противтурско осећање као израз незадовољства против Турске као политичког непријатеља и економског израбљивача готово читавог југословенског света, на једној страни, и као израз широко схваћене борбе неверника, на другој страни.“ (LETIĆ 1982: 20) Битка код Хоћина је била својеврсни догађај, какав словенски народ за време турске владавине није доживео. 
„Тај је догађај у његово доба имао невиђени одјек; он је запањио ондашњи свет својом необичношћу: до тада се није догодило да силни турски султан умре од руке својих поданика; он је на све стране продубио давнашње наде: сви су слутили скори крај Турске Царевине и сви су били сигурни у блиско ослобођење поробљених балканских народа; он је још једном свеопшту пажњу усмерио према Пољској: Османова смрт схваћена је као последица прошлогодишњег пораза који су султану задали Пољаци код Хоћина.“ (PANTIĆ 1967: 21) Хришћанска визија заступљена у делу била је заснована на контрасту и антитези између хришћанства и мухадемства, крста и полумесеца и, можда најважније за нас, пољског краљевића и турског султана.

Гундулићева пристрастност и изражено родољубље можда је још највидљивије у одступању од Аристотеловог захтева да састављач епа „сам не излази на позорницу“. Он никада не дозвољава читаоцу да сам пронађе поуку, већ је истиче и сам подвлачи. Због тога је његов приповедач заинтересован, пристрастан и субјективан. „Сликајући људе, догађаје и појаве, спомињући историјска збивања и доводећи јунаке епоса у градове и крајеве славне или пак трагичне својом прошлошћу, песник Османа непрестано према свему томе одређује, и непрестано показуje, свој однос, хвалећи или осуђујући, благосиљајући или проклињући, узносећи као пример који ваља следити или нападајући као зло кога се ваља клонити.“ (PANTIĆ 2014: 364)

Најнеобичније одступање од Тасових захтева био је одабир главног јунака. Он је морао бити носилац морално исправних одлука, увек на страни правде тако да је и крај епа морао бити срећан по главног јунака. Ово одступање је предмет нашег даљег разматрања.

\section{2. ЗАШТО ОСМАН, А НЕ ВЛАДИСЛАВ? АНТИТЕЗА ИЛИ РАВНОТЕЖА?}

Из свега што смо навели можемо закључити да се Гундулић према узорима односи на посебан начин. „Подражавање је Гундулић схватио на начин на који се оно схватало у најбољим хуманистичким расправама о поезији: то је подражавање које води жеља да се узор достигне, још више да се он, кад год је то, и у чему је год то могућно, надмаши и престигне.“ (PANTIĆ 2014: 64)

Гундулићев еп носи назив по главном јунаку Осману. Ово свесно одустајање од Тасовог захтева да главни јунак епа буде позитиван доводи у питање Гундулићеве разлоге за ово одступање, јер то он свакако није урадио без неког већ одређеног циља. „Осман је отеловљење једног греха који је Гундулић, као кристијан спјевалац и мислилац сав у водама католичке обнове, држао врло тешким и безусловно погубним: охолости; он 
je, дакле, негативан јунак, како бисмо данас рекли; и његов крај далеко од сваке среће, најбеднији и најтрагичнијим што може." (BOJOVIĆ 2014: 17) Због чега је Гундулић као 'кристијан спјевалац’ епу дао наслов Осман, по имену главног јунака и у центар збивања ставио турског султана, а не пољског краљевића? Одговор је сасвим једноставан и логичан. Да Осману није посветио толико пажње, да га није учинио централном личношћу и све што се одвија у епу подредио овом, не у потпуности, негативном лику, порука коју носи његова судбина, не би била изречена на адекватан начин. Владислав није морао да буде детаљно продубљен, јер је он више метафора него лик, приповедачев савезник, а „с обзиром на то да је у средишту збивања Осман и његова судбина, Владислав се заправо у причи није морао ни појавити, а при томе му је ипак могла бити исказана, и могао је - и не појавивши се - имати исту ону идеолошку функцију коју и овако има.“ (PAVLIČIĆ 1996: 75) Владислављева функција је да буде најчаснији представник хришћанства и морално исправних одлука и због тога му се у епу на више места певају химне и апотеозно слави његов лик и заслуге за ослобођење хришћана.

У литератури је нарочито истицано да су ликови пољског краљевића Владислава и турског султана Османа један другоме супротни. У поређењу њихових ликова суочавају се две вере, два царства, две владавине и две судбине. Супротности између два владара изражене су и описују их као ликове: „један је освајач, други брани свој народ и своју земљу, један је охол, други је смерни хришћанин, један је носилац највише хришћанске идеје, други хришћанских порока.“ (ВOJOVIĆ 2014: 17) Иако је неоспорно да су из тих разлога Осман и Владислав један другом антитеза, сличности које постоје између њих усмеравају тумачење лика султана Османа ка анализи његовог греха, не дозвољавајући да се поступци оправдају младошћу и неискуством. Обојица су млади и амбициозни владари али имају другачије односе према животу и због тога су њихове судбине различите. Османова младост је охола и неправедна, а Владислав стоји у позадини као оспоравање плахе младости, јер он, иако је млад владар, чврсто стоји на земљи. Такође у епу они имају другачије функције. Осман је ту да би у духу барокних убеђења Гундулић показао погубност охолости као једног од највећих грехова у хришћанској визији живота, а Владислав као носилац исправних хришћанских ставова треба да буде оличење моралности и праведности. Између ова два лика успостављена је равнотежа које је била потребна Гундулићу да покаже разлику између праведне и неправедне владавине.

Међутим, не може се рећи да су Осман и Владислав један другоме у потпуности супротни. У односу на Владислава, Осман није потпуна антитеза. Напротив. Гундулић није имао намеру да створи црно-беле ли- 
кове, тако да ни Осман није замишљен као лик који поседује само негативне особине, што ћемо видети у наставку анализе. „Млади цар, наиме, има многе врлине, али само један порок, и тај је довољан да га упропасти.“ (PAVLIČIĆ 1996: 75) Гордост и Османова судбина су везане једна за другу. Не можемо да говоримо о гордости у овом епу без Османа, нити да Османов лик тумачимо изостављајући његову охолост.

\section{2. ОХОЛОСТ КАО МОТИВАЦИЈА ЗА ПОЧЕТАК}

Гундулић је састављајући еп Осман, већ на самом почетку одступио од захтева нормативне поетике. Еп не почиње, како правило налаже, зазивањем муза. Обраћање музама и њихово позивање одложено је да би еп почео апострофирањем охолости, чиме би се већ у првим стиховима створила атмосфера греха:
„Ах чијем си се захвалила
ташта људска охолости?
Све што више стереш крила
све ћеш пака ниже пасти.“
(GUNDULIĆ 2001: 159)

Овим одступањем Гундулић је охолости дао највећи значај, учинивши је мотивацијом за почетак радње. Османа упознајемо у тренутку када сумира утиске о поразу код Хоћина. Монолог који је Гундулић осмислио као Османово разоткривање, показује нам не само његове утиске о поразу, него и ставове и жеље за победом. Овај монолог је кључан за анализу Османовог лика, јер у њему открива све о себи, што би, да овог монолога нема, остало на нивоу претпоставки.

Пораз код Хоћина изневерио је Османова очекивања, јер се он храбро борио у бици и очекивао је да ће његовим неустрашивим корацима, поћи и војска састављена од јањичара. Гундулић допушта Осману да проговори о себи као о храбром јунаку, који се неустрашиво борио у бици код Хоћина:

„викнух, скочих сам на коњу,

бојник уједно и војвода,

при срамотним безаконију,

не пазећи се незгода.“

(GUNDULIĆ 2001: 165)

За пораз у бици, у којој су се сукобили крст и полумесец, султан криви јањичаре, јер се нису борили храбро. Њега чуди њихова уплашеност и, мада не трудећи се да проникне дубље у разлоге за њихово повла- 
чење, разматра и пореди војне снаге обе стране:

„Ах злочести и незнани, од шта сте се», ријех’ припали?

Једа и ви, ко крстијани, по двије руке нијесте имали?

Једа и они нијесу људи?

Једа и у вас срца није?"

(GUNDULIĆ 2001: 166)

Постављајући бројна реторичка питања зауставља се на проблему некадашње храбрости турске војске и снаге какву је раније имала турска држава: „Турско старо смјенство гди је?“(GUNDULIĆ 2001: 166).

Ово је веома важан моменат у тумачењу Османовог лика. Његово алудирање на некадашњу славу и снагу Турске, само је изговор и маска за његове праве планове. „Он не жели обновити славу предака ради саме славе (наиме, ради просперитета државе), него зато да би се особно прославио, да би удовољио властитој таштини“ (PAVLIČIĆ 1996: 76) на шта нарочито указује и његово поређење са Сулејманом Величанственим и Александром Македонским у наставку монолога:

„Два цара ова још одавна

за изглед ставих жељам мојим:

њих ћу слидит дјела славна, докли нас сај свијет освојим!“

(GUNDULIĆ 2001: 167)

У жељи да освоји цео свет и тако се прослави, охоли султан прави велику грешку: сматра да зна шта му ваља чинити. Управо у томе се огледа његова охолост, која ће га довести до пропасти и пада:

„Храбреме су ове справе;

ја знам што ћу и што је тријеби!“

(GUNDULIĆ 2001: 168)

Савети које му дају Дилавер, хоџа и Казалар-ага, Осман не схвата озбиљно и не ослања се на њих, јер му њихови савети и предлози нису примарни циљ. Због тога ће он под изговором да иде на ђабу, испланирати пут на Исток како би окупио нову војску и грамзиво, пун самољубља, кренуо у освајање целог света. Не водећи рачуна о опасностима који му могу омести све планове, он верујући да је свезнајући, шаље Али-пашу да са Пољацима склопи мир, како би имао довољно времена да спроведе своје идеје.

Од тренутка када Али-паша крене у мировну мисију, радња до- 
живљава закочење, макар што се тиче главног фаблуларног тока. Међутим, епизоде које су уметнуте не дозвољавају да Османов план зачет на почетку епа падне у заборав, али султан не предузима ништа поводом његовог остварења, већ чека. Охолост је мотивација за почетак радње овог епа, или је можда прецизније рећи импулс, јер фабулу не води „напријед жеља и напор главног јунака, с обзиром на то да је Осман крајње неактиван, он кроз цијели еп чека разултате оног имплуса што га је дао на почетку; он, дакле, не предузима ништа што би вукло радњу напријед што би видљиво на њу утјецало.“ (PAVLIČIĆ 1996: 154) Како Османа не прати „спољашња“ радња, пажњу ћемо посветити његовом унутрашњем свету.

\section{3. ОСМАН КАО ЕПСКИ ЈУНАК. ПСИХОЛОШКИ ПОРТРЕТ. ХАМАР- ТИЈА (МЛАДОСТ) И ХИБРИС (ОХОЛОСТ)}

Приликом анализе Османовог лика отвара се питање грађења овог епског јунака. Како је он „јунак неделатник“, већ се у епу представља као својеврстан медитативни лик, постаје нејасно како да тумачимо Османа као епског јунака. На овај проблем нарочито указује Павао Павличић, који приликом анализе Османовог лика у епу истиче да он, с обзиром на то да поседује унутрашњи свет и јасан психолошки портрет не може бити епски јунак из неколико разлога. Прави епски јунаци немају никакаву психологију. Затим, радња нема никакав циљ који се налази изван јунака, а циљ који је себи поставио Осман (јачање турског царства и обнова славе предака) прилично је магловит, док епски јунаци имају много јасније и прецизније одређене задатке. (PAVLIČIĆ 1996: 147) Павличића Осман подсећа на јунака витешког романа:

„Готово да би се рекло како је он у сличној позицији као Don Quijote: жели дјеловати витешки (епски) у свијету који више није витешки (или није литераран) само што он тога није свјестан“ (PAVLIČIĆ 1996: 147)

Пратећи ова Павличићева тумачења и уочавајући јасну дисонанцу која се ствара између жанра и лика у њему, покушали смо да Османа анализирамо из перспективе концепта трагичке кривице, за шта су нам оправдање дали његови поступци, које смо приказали у претходним поглављима.

Осман у монологу са почетка епа говори о жељи да освоји цели свет. Наглашава да зна шта треба чинити и сматра да су планови које је сковао добри и промишљени. Због тога он током читавог епа остаје у ишчекивању тренутка када ће његови планови бити реализовани. Уколико пажњу усмеримо само ка Османовом ставу да зна шта му ваља чинити и укажемо на његову младост и неискуство, могли бисмо наше тумачење 
лика одвести у погрешном правцу и да његове поступке протумачимо као хамартију - грешку коју трагични јунак чини из незнања или се налази у некој заблуди. Неискуство младог турског султана могло би да буде оправдање и разлог за стварање осећаја емпатије према Осману. Гундулић заиста на више места у епу Османа назива „охолим дјететом“ и посвећује известан број стихова непромишљеној младости:

„О младости ташта и плаха
која срнеш с неразбора
без бојазни и без страха
гди погуба тва се отвара,
смиона си и слободна
зашто не имаш мисли у себи:
трудна дила тим су угодна
и најтежа лака теби.“
(GUNDULIĆ 2001: 170)

Подсећање на митске јунаке Икара и Геатона, који илуструју непромишљеност и плахост младости, ствара извесни амбивалентни однос према лику Османа и разлозима за његов пад. Међутим, тумачење лика Османа у контексту његове младости оспорава лик пољског краљевића. Он је оличење праведне и зреле владавине, иако је млад владар и готово једнако неискусан као и Осман. Осим тога Осман добија мудре савете старијих од себе, које не слуша и не схвата озбиљно. Осман неће страдати због тога што су његове жеље за освајањем плод неискусне и плахе младости, већ охолости. Због тога он не чини хамартију, већ хибрис - охолост, гордост и претерана самоувереност.

Његов пад није условљен незнањем, већ охолошћу, коју похрањују жеља за славом, моћи и власти. Како хибрис „није средишња карактеристика“ трагичног јунака (POPOVIĆ 2007: 261), Османа не можемо тако тумачити. Хибрис код читалаца не изазива ни страх ни сажаљење, које је Аристотел сматрао кључним за постизање катарзе у трагедији. Осман попут јунака трагедије јесте у сукобу са својим светом, али га у борбу против тог света, воде таште и охоле наде да су његове одлуке исправне и неисхитрене, правилно постављене према реалним чињеницама. Он морално није чист и код нас не може да изазове катарзу. Побуњени јањичари, Даут и Османова маћеха нису разлог због ког је Осман завршио трагично, већ он сам. Он је као охолник себи највећа препрека. „Човјек је, наиме, једино живо биће чијој заједници, па и самом његовом биолошком опстанку већа опасност пријети изнутра, него извана. Ово изнутра резултат је човјекове насилне нарави.“ (PAVEŠKOVIĆ 2004: 106).

Овакво тумачење Османовог лика јасно се може уклопити у ба- 
рокну, односно хришћанску поетику, која је нарочито утицала на разумевање појма хибрис. Такође, у складу са тим, потврђује и Гундулићеву намеру да Османа не представи као жртву, већ као грешника кога стиже казна због највећег греха који је могао починити - због његове охолости.

\section{4. БАРОКНА ВИЗИЈА ПРОЛАЗНОСТИ. БОГ И ОСМАН. ЛУЦИФЕР ПРОТИВ ОСМАНА}

Главни разлог за одступање од Тасовог захтева да радња епа не буде заснована на догађају из сувише блиске прошлости, последица је Гундулићеве родољубиве жеље да опева догађај важан за победу хришћанства и ослобођење поробљене словенске браће. Његова намера је била да овај значајан догађај у епу прилагоди барокној поетици и ставовима које је заступала хришћанска црква.

Поред питања охолости, за коју стиже казна све који живе у складу са грехом, а не Богом, у епу се разматра и пролазност и коло среће, две барокне рефлексије о животу. Пролазност је велика барокна тема, коју Гундулић није пропустио да протка кроз свој еп. Овај аспект је такође важан за анализу султановог лика, које је Гундулић свесно увео у еп.

Све на овом свету је пролазно - време, моћ и слава, успех, материјална добра и срећа. О томе казују рефлексије о пролазности и пропасти великих царстава. Тако говорећи о Троји и пустоши насталој после тројанског рата, он указује и слути могући крај турске империје.

„Гди су мири, гди су двори?

није зламенја од ничеса;

што огњу оста, вријеме обори

и похара и поплеса.“

(GUNDULIĆ 2001: 239)

Човек и све што он створи предвиђено је да нестане, јер су само Божја дела вечна.

„Вјековите и без свхре

није под сунцем крепке ствари,

а у висоцијех гора врхе

најприје огњен тријес удари.“

(GUNDULIĆ 2001: 239)

Све што у животу човек направи, није створио својом заслугом, већ уз помоћ Бога, чије законе смртник треба да поштује:

„Без помоћи вишње с неби

свијета је ставност свијем бјегућа: 
сатиру се сама у себи

силна царства и могућа.“

(GUNDULIĆ 2001: 159)

Како је Осман охолник, а изнад свега непријатељ хришћана, њему Бог не може бити наклоњен. Помоћ му не може доћи с неба, јер он није хришћанин који верује у Бога и узда се у праведност његових одлука. Гундулић као један од аспеката пролазности у еп уводи и коло среће, односно говори о пролазности среће, која не зависи од нас самих, већ од дела које чинимо и закона које поштујемо. Гундулић „показује како је Османова пропаст нужно произашла из његове охолости“; али и да „су вријеме и начин те пропасти били сасвим непредвидиви, јер то је овисило о колу од среће, односно, у крајњој конзеквенцији, о Божјој вољи. Он тврди како човјек, додуше, јест слободан у избору добра или зла, али такођер тврди да се механизам награде и казне не може јасно видјети, него да се сватко мора поуздати - мора се поуздати прије свега вјерник - да та законитост доиста постоји и да је праведно. “(PAVLIČIĆ 1996: 173)

„Целу судбину свог јунака, несрећног и премладог Османа, он је схватио као илустрацију старог католичког уверења о неминовној пропасти која стиже све охоле, али и оног другог да 'коло среће уоколо вртећи се не престаје’ и да се зато ништа не може подучити трајношћу.“ (PANTIĆ 1960: 35)

„Коло од среће уоколи

Вртећи се не пристаје:

Тко би гори, ето је доли,

А тко доли, гори остаје.“

(GUNDULIĆ 2001: 159)

Иако у овом епу нема директног мешања виших сила, у барокним и хришћанским оквирима Гундулић је поделио оноземаљски свет на рај и пакао. Поред бројних антитеза и стварања ликова у пару, Богу, ког додуше не видимо у епу, али осећамо његову праведност, супротставио је Луцифера, охолог владаоца пакла, који је у епу представљен као савезник Турака. Гундулић жели да покаже да су Османове одлуке биле лоше, непромишљене и неуједначене и да је остао без заштите владара пакла. Османова одлука да пошаље Али-пашу да склопи мир са Пољацима, разљутила је Луцифера:

„Османовић, цар на царим,

Толико се сад потиште

Да понижем с поклисарим

Мур у лешке круне иште. 
На глави му тешко бреме:

3бјен је, за утећ хуће штете,

Примит с очим зажетијеме

Од крвника сваке увјете.

Ну по вољи, али усиљен

Ако Осман Лека моли,

Поклонуту се неће умиљен

Вик никому пако охоли!“

(GUNDULIĆ 2001: 355)

Тако се појачава утисак остављеног Османа са његовом охолошћу, да настави сам у складу са својим таштим и плахим плановима освајање читавог света.

\section{5. ОХОЛОСТ КАО МОТИВАЦИЈА ЗА КРАЈ - ЦЕЛИНА И ПАД}

Гундулић је приликом састављања епа мењао извесне историјске чињенице, управљајући њима, како би их усмерио и усидрио у барокни свет. Ипак, није одступио од краја, који је и у историји био трагичан по султана Османа. Међутим, Гундулићева жеља није била да само преприча један историјски догађај и литерарно га уобличи, већ да објасни разлоге за султанов пад.

Осману је опасност претила са више страна, а чини се да он опомене и савете није схватио озбиљно. Важан моменат у овом епу јесу Дилаверови савети о томе како треба да се понаша један владар према својим поданицима, да буде увек на опрезу и да мудро сваку ситуацију окрене у своју корист. Нажалост, Осман у својој охолости не може да схвати речи свог добронамерног саветника. Гундулић „разрађује читаву малу филозофију владања: о путу до успеха не борбом, већ придобијањем непокорних; о чувању тајне када се предузимају велики подухвати, о уздржавању од радова који доносе више штете но користи; о опрезном поступању са непријатељем који части одвеће.“" (BOJOVIĆ 1995: 91-92) Та филозофија се не поклапа са охолом животном филозофијом султана Османа и уместо да као млад владар, учи и слуша старије и искусније, он ће због самољубља и загрижености за власт и моћ изгубити контролу над својом владавином.

Највећа претња долазила је од његове маћехе, мајке полубрата Мустафе, која је заједно са Даутом била у дослуху са незадовољним јањичарима. Сазнавши за Османове планове, озлојеђени јањичари су одлучили да га свргну са власти и на његово место поставе Мустафу. Осман је после оклевања и савета које је овог пута сам тражио од својих савезника, одлучио да склопи мир са побуњеном војском. Међутим, неискусно, 
остао је без страже. Заслепљен својом охолошћу он допушта јањичарима да га сустигну и ухвате неспремног и незаштићеног. Султан ни тада не може да схвати да његово царство није вечно и да му се ближи крај. У његовом дијалогу са јањичарима, делује наивно и помало недолично када покушава да им објасни и опомене да то што раде никако не смеју:

$$
\begin{aligned}
& \text { „’Тко на цара' цар завика, } \\
& \text { 'згор од Бога посвећена } \\
& \text { ставља руке, кога слика } \\
& \text { сд свијета се клада сјена?'“ } \\
& \text { (GUNDULIĆ 2001: 446) }
\end{aligned}
$$

Али, они му врло јасно понављају концепт о пролазности среће: „Ти нас си ово научио“

носећи га војска гласи

„нег неправо затворио

цара и свеца нашег си.

(GUNDULIĆ 2001: 446)

Целина која је направљена на крају епа, повезује прва певања и ствара јаку контрастну слику. На почетку епа упознали смо Османа у сјају и на врхунцу моћи и слика његовог физичког портрета док седи на престолу, упечатљива је толико да је до краја епа нисмо могли заборавити. Сада се све окреће против охолости и ствара се својеврсни контраст заснован на времену, које је све само не стално и укорењено.

Овако је Гундулић на почетку епа описао турског султана:

„У зеленој туј хаљини,

Злато и бисер ку накити,

С подвитијем сприд колини

Сједи Осман цар честити.

Вео на русој глави около

Снјежан свит му је сто дијела,

А у камену драгу охоло

Сунце цја му врх чела.“

(GUNDULIĆ 2001: 172)

Охолост је као један од највећих грехова у хришћанској визији морао бити кажњен. Гундулић у јасном контрасту показује пад султана. Величанственој слици Османа на престолу Гундулић супротставља пораженог султана, кога воде, побуњени јањичари као роба:

„Овако се Осман млади, цар од цара цвијех највећи, 
на једнога коља усади, ки се нађе туј и припросто само згар га одијаваше, без хаљине будућ осто, с ком врх сунца њекад сјаше.“

(GUNDULIĆ 2001: 445)

Коло среће затвара свој круг када на Османово место ступа Мустафа:

„Цар Мустава на висини, свијетло урешен и богато, сјаше царској у хаљини; пристоље му је сухо злато.“ (GUNDULIĆ 2001: 447)

Функција кола среће, јете да опомене и пошаље поуку:

Ах, овако срећа врти уоколо коло своје!“ „Научите људи охоло, ки живете без припасти, да није тврђе крепке доли ка не може часом пасти. (GUNDULIĆ 2001: 449)

Иако је више него јасно да је његовој владавини, а тиме уједно и његовом животу дошао крај, Осман не прихвата своју судбину, како би учинио трагични јунак, већ се понаша прилично недолично:

„А он вапијаше свеђ из гласа:

Једа људи, једа Бога!

Ко ми граби сабљу с паса

И сто отимље царство мога?

Ја сам, ја син цару Ахмату, првородно дијете своје;

Мени, мени, а не брату

Царство од оца остало је.“ (GUNDULIĆ 2001: 448)

Његово погубљење, додатно је понижење за охолог цара, кога дави роб, црнац:

„Под ногами роба свога

умрије овако цар од свијета 
И под ноге испод нога

Укопа се прешно опета."

(GUNDULIĆ 2001: 458)

Гундулић на крају епа сумира Османову судбину и разлог његовог пада. Указује на погубност охолости, која даје уверење човеку да има права да влада и поробљава, да је његова власт на земљи већа од божје, што је одвело Османа у пропаст :

„Ну влас божја брзо у себи

самосиља крши и слама, за указат да на неби

И на земљи она је сама.

Ти у живот цара свети и под ноге све му стлачи, хтећ да роб је све на свијети, а сам он врх свијех јачи.

Ну власт божја, кој имају поклањат се људи сами, хтје да пусти душу у вају цар свом робу под ногами.“ (GUNDULIĆ 2001: 460-461)

\section{6. ЗАКЉУЧАК}

Предмет овог рада била је анализа Османовог лика у истоименом епу, најзначајнијег писца барокног епа у старом Дубровнику, Џива Гундулића. Овај плодни и надасве оригинални писац, био је патриота и верник. Као барокни човек, Гундулић је према греху гајио својеврсну одбојност и овим епом је хтео да покаже погубност коју производи охоло опхођење. Приликом састављања Османа, Гундулић је повремено одступао од правила нормативне поетике Торквата Таса, и тако створио сопствену поетику. Једно од правила било је то да се за предмет обраде никако не узима догађај из ближе хришћанске историје. Ипак, битка код Хоћина је била својеврсни догађај никада виђен у дугој историји робовања хришћана под Турцима. Гундулић је одлучио да исприча овај догађај и тако споји две визије -словенску и хришћанску - што је успешно и учинио. Еп је насловио именом негативног јунака и одступивши од правила учинио га је централном личношћу епа. У анализи Османовог лика, тражили смо разлоге због којих је Гундулић одустао да Владислав буде главни јунак. Закључили смо да је лик Владислава послужио као метафора за све што је праведно и морално исправно. Због тога није било по- 
требе да његов лик продубљује, већ су сва пажња и простор епа усмерени ка Осману. Гундулићу је Владислав послужио не само као антитеза, већ и равнотежа главном јунаку. Објаснили смо да поред бројних супротности, постоје и извесне сличности између ова два лика - обојица су млади владари, тако да ни младост на коју је и сам Гундулић скретао пажњу не би могла да буде оправдање Осману за његове поступке. Анализирајући Османов лик уочили смо потребу да пажњу посветимо његовом психолошком аспекту. С обзиром на то да лик има унутрашњи свет, не можемо га објаснити као епског јунака. Покушали смо да Османа представимо као трагичног јунака, који грешку чини из незнања или заблуде (хамартија). Његове поступке нисмо могли оправдати младошћу и неискуством, јер је њему све време супротстављен млади пољски краљевић. Када бисмо, ипак, Османове освајачке амбиције оправдали незрелошћу, дошли бисмо до закључка да он није страдао због жеље да прошири границе своје земље. Разлог његовог пада је охолост, коју су створиле његове амбиције за освајањем, славом, моћи и власти. Хибрис као синоним за гордост, који одређује Османов лик не дозвољава да га тумачимо као трагичног јунака, јер он не изазива ни страх ни сажаљење код нас. Гундулићева намера није била да представи трагичног јунака, већ грешника, чији ће поступци и казна која следи бити опомена читаоцима.

Гундулић је охолости као једној од највећих грехова дао кључне функције у овом епу - она је мотивација за почетак радње, али и њен крај. Гордост је, наиме, почетни импулс, грудва снега која почиње своје неумитно котрљање ка коначном паду и лому. Разлог за Османов пад тражили смо у његовој охолости, али нисмо могли да изоставимо и не укључимо у разматрање пролазност и коло среће, односно да су време и начин његове пропасти били непредвидиви, јер је све зависило у ствари од божје воље. Како је Осман био друге вере, њему Бог, чија су дела вечна, није био наклољен. Гундулић иде и корак даље одвојивши Османа од Луцифера, заштитника муслимана и остављајући га на тај начин без икакве заштите оноземљских сила. Осман, пошто се оглушио о све савете, које је добио од својих верних поданика, одлучио је да остане и без страже, последње заштите коју је имао. Неопрезност султана, искористили су незадовољни јањичари. Гундулић затвара причу о охолом султану Осману колом среће и опоменом, у складу са епохом, јасно поцртаном поуком. У контексту тумачења јунака Османа можемо закључити да је он представник свих оних људи, који због охолости и заслепљени жељом за моћи и власти, морају нужно пропасти. 


\section{Цитирана литература}

BOJOVIĆ, Zlata. Osman Dživa Gundulića. Beograd: Zavod za udžbenike i nastavna sredstva. 1995. [orig.] БОЈОВИЋ, Злата. Осман Џива Гундулића. Београд: Завод за уџбенике и наставна средства, 1995.

BOJOVIĆ, Zlata. Dživo Gundulić. Novi Sad: Matica srpska, 2014. [orig.] БОЈОВИТ, Злата. Џиво Гундулић. Нови Сад: Матица српска, 2014.

KILIBARDA, Novak. Iz korijena usmenosti. Priština: Jedinstvo, 1988. [orig.] КИЛИБАРДА, Новак. Из коријена усмености. Приштина: Јединство, 1988.

LETIĆ, Branko. Rodoljublje u dubrovačkoj književnosti. Sarajevo: Svjetlost, 1982.

PANTIĆ, Miroslav. „Poetika Gundulićevog 'Osmana'. Osman, Dživo Gundulić. Beograd: Srpska književna zadruga, 1967. [orig.] ПАНТИЋ, Мирослав. „Поетика Гундулићевог 〈Османа〉“. Осман, Џиво Гундулић. Београд: Српска књижевна задруга, 1967.

PANTIĆ, Miroslav. „Poetika Gundulićevog Osmana“. Dživo Gundulić. Priredila Zlata Bojović. Novi Sad: Matica srpska, 2014. [orig.] ПАНТИЋ, Мирослав. „Поетика Гундулићевог Османа“. Џиво Гундулић. Приредила Злата Бојовић. Нови Сад: Матица српска, 2014.

PANTIĆ, Miroslav. Dubrovačka književnost. Beograd: Rad, 1960. [orig.] ПАНТИЋ, Мирослав. Дубровачка кюижевност. Београд: Рад, 1960.

PAVEŠKOVIĆ, Antun. „Gundulićev Osman kao antropološki problem“. Anali. svezak XLII. Zagreb: Zavod za povijesne znanosti hrvatske akademije umetnosti u Dubrovniku, 2004.

PAVLIČIĆ, Pavao. Studije o Osmanu. Zagreb: Zavod za znanost i književnost Filozofskog fakulteta Sveučilišta, 1996.

TODOROVIĆ, Jelena. O ogledalima, ružama i ništavilu. Koncept vremena i prolaznosti u kulturi baroknog doba. Beograd: Clio, 2012. 
Mirjana Krtolica

GUNDULIĆ'S OSMAN BETWEEN HAMARTIA AND HIBRIS: THE VICTIM OF HIS YOUTH OR HIS VANITY

This paper sums up the results obtained by analyzing the character of Sultan Osman II in the Gundulićs epic from two perspectives: a tragic hero and a vain hero. The analysis is dominated by the concepts of the baroque sinner and the ancient tragic hero. The paper draws conclusions about the possibilities for the hero to be interpreted as a tragic hero and the limitations that challenge this claim. In the context of Baroque literature, the analysis is dominated by the conventions of the epoch in which the work originated, and the work draws conclusions in favor of the claim that Osman is not a tragic hero and he does not make hamartia, a mistake out of ignorance, but his downfall is a consequence of a hibris, a tragic guilt and an outcome of excessive vanity. This fact does not allow us to interpret him as a tragic hero, because he does not provoke fear or pity in us. Gundulićs intention was not to present a tragic hero, but a sinner, whose actions and the punishment that follows will be a warning to readers.

Key words: Dživo Gundulić, Baroque epic, epic Osman, Osman II, hamartia, hibris, tragic hero, vanity 